\title{
Efficiency of a constructed wetland for wastewaters treatment
}

Eficiência de um "wetland" construído no tratamento de efluentes

Fernanda Travaini-Lima and Lúcia Helena Sipaúba-Tavares

Laboratório de Limnologia e Produção de Plâncton, Centro de Aquicultura, Universidade Estadual Paulista - UNESP, CEP 14884-900, Jaboticabal, SP, Brazil email: nandatravaini@gmail.com; sipauba@caunesp.unesp.br

\begin{abstract}
Aim: The limnological characteristics of three different inlets water of the constructed wetland were compared in terms of concentration data and loading rate data and evaluated the removal efficiencies of nutrients, solids, $\mathrm{BOD}_{5}$, chlorophyll-a and thermotolerant coliforms (TC) by the treatment system; Methods: The constructed wetland, measuring $82.8 \mathrm{~m}^{2}$ and with detention time of 1 hour and 58 minutes in the rainy season and 2 hours and 42 minutes in the dry one, was provided with four species, Cyperus giganteus Vahl, Typha domingensis Pers., Pontederia cordata L. e Eichhornia crassipes (Mart.) Solms. The sampling sites evaluated in the dry (D) and rainy (R) seasons were: inlet water from aquaculture farm = IA; inlet channel of rainwater runoff $=I R$; inlet from UASB wastewater = IB; outlet wetland $=$ OUT. The conductivity, $\mathrm{pH}$, temperature, dissolved oxygen, alkalinity, $\mathrm{BOD}_{5}$, total soluble and dissolved solids, nitrogen, phosphorus, chlorophyll-a and TC were analyzed. Multivariate analyses, such as Cluster and Principal Components Analysis (PCA), were carried out to group sampling sites with similar limnological characteristics; Results: In the PCA with the concentration data was retained $90.52 \%$ variability of data, correlating the inlet IB with high concentrations of conductivity, alkalinity, $\mathrm{pH}, \mathrm{TC}$, nutrients and solids. Regarding loading rate data, the PCA was retained $80.9 \%$ of the data's total variability and correlated the sampling sites IA D, IA R and OUT R with higher $\mathrm{BOD}_{5}$, chlorophyll-a, TDS, nitrate, nitrite, total-P, temperature, oxygen and water flow. The highest removal efficiencies rates occurred in the dry season, mainly in concentration, with $78 \%$ of ammonia, $95.5 \%$ of SRP, $94.9 \%$ of TSS and 99.9\% of TC; Conclusions: The wetland was highly efficacious in the removal of nutrients, solids, $\mathrm{BOD}_{5}$, chlorophyll-a and TC, mainly during the dry season. The system restructuring to increase the detention time during the rainy season and a pre-treatment of UASB wastewater, can increase the retention of nutrients and solids by wetland.
\end{abstract}

Keywords: constructed wetland, macrophyte, removal efficiency, hydraulic flow, loading rate.

Resumo: Objetivo: Comparar as características limnológicas de três diferentes entradas de água no "wetland" construído, com dados de concentração e carga, e avaliar a eficiência de remoção de nutrientes, sólidos, $\mathrm{DBO}_{5}$, clorofila-a e coliformes termotolerantes (TC) pelo sistema de tratamento; Métodos: No "wetland" construído, com área total de $82.8 \mathrm{~m}^{2}$ e tempo de residência de 1 hora e 58 minutos na estação chuvosa e 2 horas e 42 minutos na seca, foram utilizadas as espécies Cyperus giganteus Vahl, Typha domingensis Pers., Pontederia cordata L. e Eichhornia crassipes (Mart.) Solms. Os pontos de amostragem avaliados em períodos de seca (D) e chuva (R) foram: entrada de água proveniente de aquicultura = IA; canal de entrada de escoamento da chuva = IR; entrada de resíduos provenientes de biodigestores = IB; saída de água do "wetland" = OUT. As variáveis analisadas foram: condutividade, $\mathrm{pH}$, temperatura, oxigênio dissolvido, alcalinidade, $\mathrm{DBO}_{5}$, sólidos particulados e dissolvidos, nitrogênio, fósforo, clorofila-a e TC. Análises estatísticas multivariadas de Agrupamento e Componentes Principais (ACP) foram usadas para agrupar pontos de amostragem com características limnológicas semelhantes; Resultados: Na ACP com dados de concentração foi retido $90.52 \%$ da variabilidade dos dados, correlacionando a entrada IB com altas concentraçóes de condutividade, alcalinidade, $\mathrm{pH}, \mathrm{TC}$, nutrientes e sólidos. Para os dados de carga a ACP reteve $80.9 \%$ da variabilidade dos dados e correlacionou os pontos IA D, IA R e OUT $\mathrm{R}$ com elevada $\mathrm{DBO}_{5}$, clorofila-a, STD, nitrato, nitrito, P-total, temperatura, oxigênio e vazão. As maiores taxas de eficiência de remoção ocorreram na seca, principalmente em concentração, com $78 \%$ para amônia, $95.5 \%$ para SRP, $94.9 \%$ para STS e $99.9 \%$ para TC; Conclusóes: O "wetland" foi eficiente na remoção de nutrientes, sólidos, $\mathrm{DBO}_{5}$, clorofila-a e TC, principalmente no período seco. Reestruturaçôes do sistema para aumentar o tempo de residência durante as chuvas e um pré-tratamento dos resíduos de biodigestores, podem aumentar a retenção de nutrientes e sólidos pelo wetland.

Palavras-chave: "wetland" construído, macrófitas aquáticas, eficiência de remoção, fluxo hidráulico, carga. 


\section{Introduction}

Intense development in aquaculture and other agricultural and cattle-raising forms have caused an increase in environmental impacts. The culture of water organisms produces solid wastes (feed wastes, feces and others) and dissolved matter (Sindilariu et al., 2009) which are transported out of the culture system through effluents rich in organic and inorganic compounds such as ammonia, phosphorus, dissolved organic carbon and organic matter (Crab et al., 2007). All these factors may cause eutrophication and other deleterious effects in the receiving water bodies (Pistori et al., 2010; Konnerup et al., 2011).

The rapid expansion in the production of cattle has in a similar way produced a large amount of concentrated animal wastes that are dumped into the environment (Stone et al., 2004) while anaerobic digestion, such as that carried out by Upflow Anaerobic Sludge Blanket (UASB), have been employed for waste treatment (Oliveira and Santana, 2011). However, doubts exist on the capacity of the above treatment technologies to reach acceptable quality levels of the effluent especially when they are compared to aerobic processes (Von Sperling and Oliveira, 2009). Since effluents from anaerobic treatments have a large loading rate of solid and dissolved wastes from organic compounds, they should undergo a second treatment so that standards of effluent discharges in water sources could be complied with (Barros et al., 2008; An et al., 2010).

Constructed wetlands are one of the most promising methods for effluent treatment for wastewater of biodigesters and aquaculture, mainly in Brazil (Henry-Silva and Camargo, 2008; Sipaúba-Tavares and Braga, 2008; Toledo and Penha, 2011). The system is based on physical, chemical and biological processes and may deal with a great variability of pollutant load characterized by high concentration and great water flow (Brix et al., 2007; Sindilariu et al., 2009). Further, systems with ornamental macrophytes may provide a highly pleasing environment (Zurita et al., 2009).

The performance of constructed wetlands depends on microbial activity, hydraulic retention time, load, temperature and types of vegetation (El-Khateeb et al., 2009). Precipitation and evapotranspiration are some climatic factors that have an important role in the performance of treatments under tropical and subtropical conditions. During the rainy season excessive precipitation may drastically alter water levels in constructed wetlands and cause contaminant dilution and modifications in the water chemistry (Katsenovich et al., 2009).

The wetland under analysis treats not only the water from the aquaculture farm but also rainwater runoff through a channel and wastes from the animal feces-processing anaerobic biodigesters (Sipaúba-Tavares and Braga, 2008). It may be supposed that the inlets have distinct concentrations and loads and may alter the removal efficiency of wetland. Current study was aimed to i) compare the limnological characteristics of three different inlets water of the constructed wetland in terms of concentration data and loading rate data; ii) evaluate the removal efficiencies of nutrients, solids, $\mathrm{BOD}_{5}$, chlorophyll-a and thermotolerant coliforms of a constructed wetland.

\section{Methods}

\subsection{Study area}

Current study was carried at the Aquaculture Center Brazil $\left(21^{\circ} 15^{\prime} \mathrm{S}, 48^{\circ} 18^{\prime} \mathrm{W}\right)$ in a constructed wetland to treat an aquaculture effluent from a set of ponds placed in a sequence and in continuous flow. They receive water from the water source, water tanks and small ponds and from the culture sector of ornamental fish, frog and shrimps (SipaúbaTavares et al., 2010). The constructed wetland also receives water from surface rain runoff through a channel during the rainy season (summer) and water inlet from swine wastewater, treated in Upflow Anaerobic Sludge Blanket (UASB), with matter discharge when reactors are switched on.

The constructed wetland has a surface area of $82.8 \mathrm{~m}^{2}$ and $0.30 \mathrm{~m}$ deep; soil consisted of eutrophic dark red latisol of a highly clayey texture; water flowed directly on the ground covered with pebbles. The system was provided with three round plastic boxes, measuring approximately $0.64 \mathrm{~m}^{2}$ and $0.55 \mathrm{~m}$ high, with several apertures, each with $38.5 \mathrm{~mm}^{2}$ diameter, at two opposite sides of the water flow. The floor of the boxes was covered with pebbles and the floating macrophyte Eichhornia crassipes (Mart.) Solms was placed on the water surface (Figure 1).

A plastic barrel with a lid and several side apertures for water flow, containing small plastic substrates, provided the growth of anaerobic bacteria. Two rectangle boxes, $0.18 \mathrm{~m}^{2}$ and $0.30 \mathrm{~m}$ high, made of the same material of the other boxes and the barrel, with side apertures and filled with pebbles, were placed one near the inflow, and the 


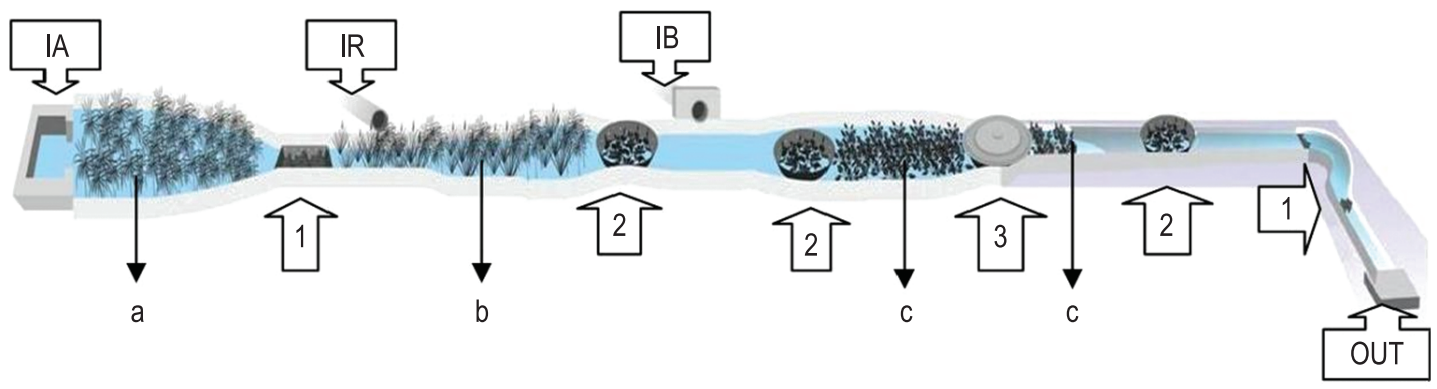

Figure 1. Layout of a constructed wetland, showing the three inlets water: inlet water from aquaculture farm = IA; inlet channel of rainwater runoff $=$ IR; inlet from UASB wastewater $=I B$; outlet wetland $=$ OUT, where: $1=$ rectangular plastic box; 2 = plastic barrel with pebbles in the bottom and Eichhornia crassipes on the surface; 3 = plastic barrel covered with pieces of plastic as a substrate; $\mathrm{a}=$ Cyperus giganteus; $\mathrm{b}=$ Typha domingensis; $\mathrm{c}=$ Pontederia cordata.

other close to the water outflow, to slow the velocity of the water and enhance the growth of periphyton adhered to the stones (Figure 1).

Whereas Cyperus giganteus Vahl and Typha domingensis Pers. were planted close to the inflow channel, Pontederia cordata L. was planted at a distance of approximately $25 \mathrm{~m}$ from the effluents inflow, close to a shaded area. The planted area was equivalent to $43.5 \%$ of the channel's total area (Figure 1).

\subsection{Sampling and analyses}

Water samplings for the determination of limnological characteristics were undertaken always in the morning during six months at two climatic periods. The first period was between January to March $2008(n=6)$ during the rainy season and the second period was between June to August $2008(n=8)$ during the dry season. Samples were taken regularly at the water surface and $10 \mathrm{~cm}$ from the inlet channels and outlet wetland. The sampling sites evaluated were: inlet water from aquaculture farm = IA R (rainy season) and IA D (dry season); inlet channel of rainwater runoff = IR (only during the rainy season, because there were no runoff during the dry season); inlet from UASB wastewater = IB (only during the dry season, since no discharge occurred during the rainy season); outlet wetland = OUT R (rainy season) and OUT $\mathrm{D}$ (dry season).

Conductivity (Cond), $\mathrm{pH}$ and water temperature $\left({ }^{\circ} \mathrm{C}\right)$ were measured in situ with a portable meter Horiba U-10, and dissolved oxygen (DO) with a handheld dissolved oxygen meter YSI-55. Total soluble solids (TSS), total dissolved solids (TDS) and biochemical oxygen demand $\left(\mathrm{BOD}_{5}\right)$ were determined according to Boyd and Tucker (1992).
Alkalinity (Alk) was measured following techniques by MacKereth et al. (1978). Nitrate $\left(\mathrm{NO}_{3}\right)$, nitrite $\left(\mathrm{NO}_{2}\right)$, total phosphorus (TP) and soluble reactive phosphorus (SRP) by Golterman et al. (1978) and ammonia $\left(\mathrm{NH}_{4}\right)$ by Koroleff (1976). Chlorophyll-a (Chl-a) and thermotolerant coliforms (TC) were determined by methods following Nusch (1980) and Greenberg et al. (1992), respectively. Analyses were performed immediately after sampling or samples were duly stored under refrigeration. Air temperature and precipitation data were obtained from the Agroclimatological Station of UNESP in Jaboticabal SP Brazil, some $415 \mathrm{~m}$ from the experiment site.

Data on water flow rate at the inlets and outlet of the constructed wetland were obtained in triplicate in all samplings, with mean given in $\mathrm{m}^{3} \cdot \mathrm{h}^{-1}$. The hydraulic loading rate (HLR) of the constructed wetland was calculated for the dry and rainy seasons by equation $\mathrm{q}=\mathrm{Q} / \mathrm{A}$, where $\mathrm{q}$ is the hydraulic loading rate (HLR) $\left(\mathrm{m} . \mathrm{h}^{-1}\right)$; $\mathrm{Q}$ is the water flow rate $\left(\mathrm{m}^{3} \cdot \mathrm{h}^{-1}\right)$ and $A$ is the wetland area (wetland land area) $\left(\mathrm{m}^{2}\right)$. Detention time for the two seasons was measured by equation $T_{r}=V / Q$, where $\mathrm{T}_{\mathrm{r}}$ is the detention time (hours); $\mathrm{V}$ is the maximum volume of the channel $\left(\mathrm{m}^{3}\right)$ and $\mathrm{Q}$ is the water flow rate $\left(\mathrm{m}^{3} \cdot \mathrm{h}^{-1}\right)$. The loading rate was calculated from each inlet and outlet of the constructed wetland by equation $\mathrm{m}=\mathrm{q} \cdot \mathrm{C}$ where $\mathrm{m}$ is the (specific) loading rate $\left(\mathrm{g} \cdot \mathrm{m}^{-2} \cdot \mathrm{d}^{-1}\right) ; \mathrm{q}$ is the hydraulic loading rate (HLR) (m. $\mathrm{h}^{-1}$ ) and C is the concentration $\left(\mathrm{mg} \cdot \mathrm{m}^{-3}\right)$. The removal percentage of nutrients, solids, $\mathrm{BOD}_{5}$, chorophyll-a and TC by the constructed wetland was measured by the formula: $\%$ removal efficiency $=\left[\left(\Sigma \mathrm{m}_{\mathrm{i}}-\mathrm{m}_{\mathrm{o}}\right) / \Sigma \mathrm{m}_{\mathrm{i}}\right] .100$, where $\Sigma \mathrm{m}_{\mathrm{i}}$ is the sum of inlets of loading rates or concentrations and $\mathrm{m}_{\mathrm{o}}$ is the outlet of loading rates or concentrations. 


\subsection{Statistical analysis of data}

Concentration data and loading rate data were submitted separately to Multivariate Cluster Analysis performed by Ward's method and the similarities-dissimilarities quantified through Euclidean distance measurements to sort sampling sites into groups with strong degree of association between members of the same cluster. To clarify the correlation between the limnological variables and clustering sampling sites was performed two Principal Component Analysis (PCA) for concentration data and loading rate data, to reduce the data dimensionality in two bi-dimensional graphs (Kindt and Coe, 2005). Only components with eigenvalues higher than 1 were analyzed, following Kaiser Normalization criterion (1958). The concentration data and the loading rate data were evaluated separately to identify data patterns according to the variation of the water flow in the constructed wetland. The statistical analyses were carried out by Statistica 8.0 (STATSOFT, 2007).

\section{Results}

Rates of flow and hydraulic loading during the rainy season were higher than those during the dry one, respectively $41.6 \mathrm{~m}^{3} \cdot \mathrm{h}^{-1}$ to $30.6 \mathrm{~m}^{3} \cdot \mathrm{h}^{-1}$ and $0.50 \mathrm{~m} \cdot \mathrm{h}^{-1}$ to $0.37 \mathrm{~m} \cdot \mathrm{h}^{-1}$. On the other hand, rates for detention time were 2 hours and 42 minutes during the dry season and 1 hour and 58 minutes during the rainy one. Monthly mean for air temperature and water temperature were higher during the rainy season (summer), with $23.5^{\circ} \mathrm{C}$ and $26.7^{\circ} \mathrm{C}$ and in the dry season at $20.1{ }^{\circ} \mathrm{C}$ and $19.8^{\circ} \mathrm{C}$, respectively. The precipitation mean between January to March was $245.4 \mathrm{~mm}$ and between June to August was $11.8 \mathrm{~mm}$ (Figure 2).
The Cluster Analysis with the concentration data of water variables showed that sampling sites constituted three main groups. Cluster I consisted of sites IA D and OUT D; cluster II comprised sites collected during the rainy season, namely, IA R, OUT R and IR; cluster III was only made up by site IB (Figure 3). In the Analysis of Principal Components with the concentration data of variables only the first two axes were taken into account. In fact, they comprised $90.52 \%$ of total data variability where axis 1 was related to the wetland's water quality which explained $78.40 \%$ of the original variability data. According to cluster analysis, group II was negatively bound to this axis and associated with high temperature, water flow, high concentrations of chlorophyll-a and $\mathrm{BOD}_{5}$, mainly at the sites which correspond to water inflows wetland. Highest concentrations in ammonia, nitrite, SRP, Total P, TDS, TSS, TC, conductivity, alkalinity and $\mathrm{pH}$ were positively related to axis 1, similar to IB. Axis 2 of the Principal Components Analysis had $12.1 \%$ of the original variability data. Dissolved oxygen, nitrate, $\mathrm{pH}$ and low temperatures were positively related to this axis and characterized group I of the Cluster Analysis. In short, data from Cluster Analysis from Principal Components Analysis showed that inflow IB was the site with the highest concentration of nutrients, solids and TC (Figure 3).

Regarding loading rate data of the limnological variables, the Cluster Analysis also grouped the sampling sites in three main groups. Cluster I consisted of sites IA D, IA R and OUT R, whereas cluster II comprised sites OUT D and IR and cluster III included only site IB (Figure 4). Only the first two axes of the Principal Components Analysis with loading rate data were employed

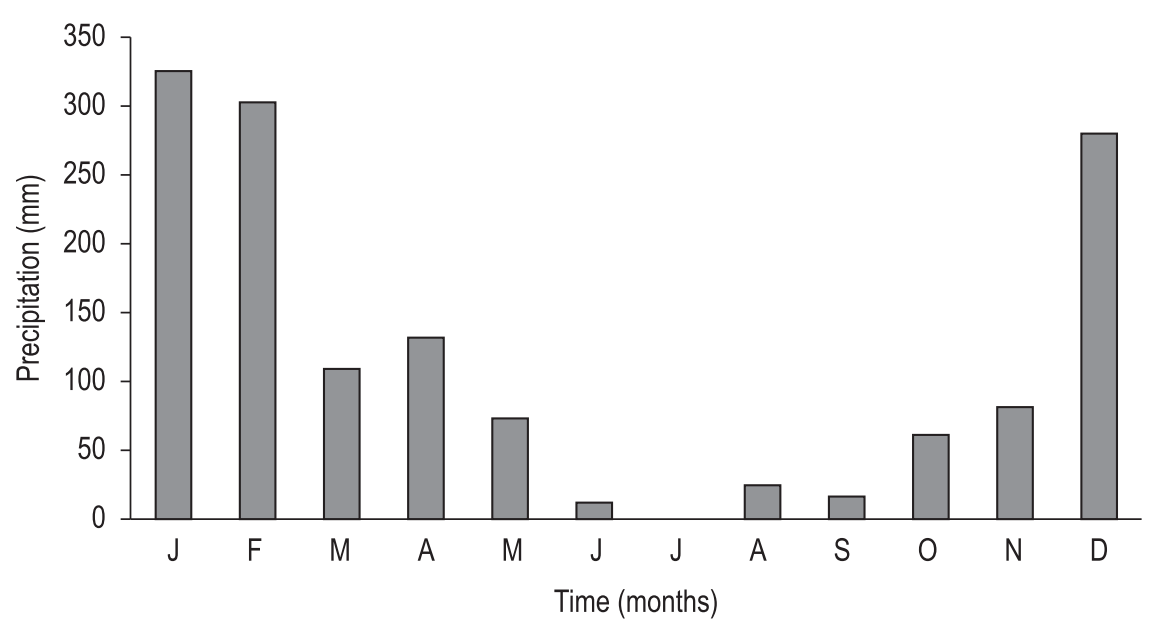

Figure 2. Seasonal variation of average monthly precipitation $(\mathrm{mm})$ during the experimental period. 


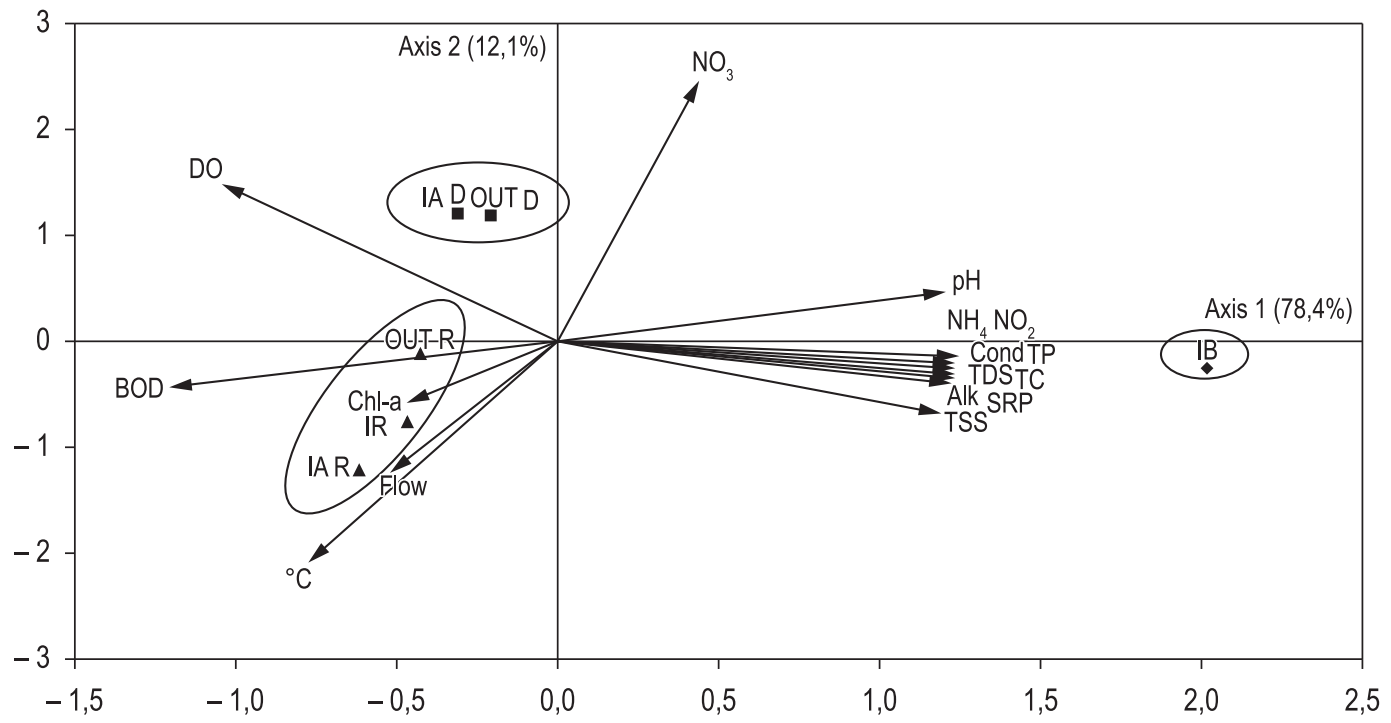

Figure 3. PCA Biplot (axes 1 and 2) complemented by Cluster Analysis of sampling sites and vectors with data for flow, temperature, $\mathrm{pH}$, conductivity and concentrations data $\left(\mathrm{mg} \cdot \mathrm{L}^{-1}\right)$ of limnological variables. Inlet water from aquaculture farm = IA R (rainy season) and IA D (dry season); inlet channel of rainwater runoff = IR; inlet from UASB wastewater $=$ IB; outlet wetland $=$ OUT R ( rainy season) and OUT D (dry season).

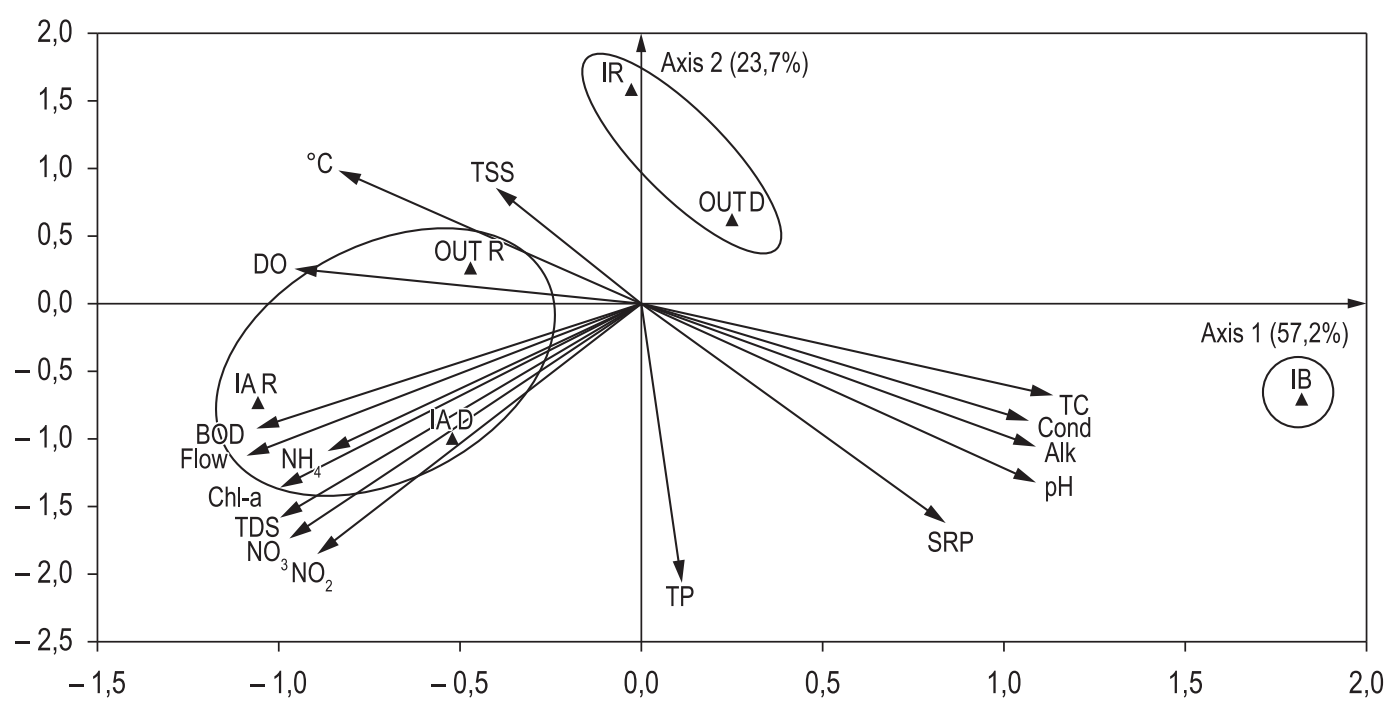

Figure 4. PCA Biplot (axes 1 and 2) complemented by Cluster Analysis of sampling sites and vectors with data for flow, temperature, $\mathrm{pH}$, conductivity and loading rate data $\left(\mathrm{g} \cdot \mathrm{m}^{-2} \cdot \mathrm{d}^{-1}\right)$ of limnological variables. Inlet water from aquaculture farm = IA R (rainy season) and IA D (dry season); inlet channel of rainwater runoff = IR; inlet from UASB wastewater = IB; outlet wetland $=$ OUT R (rainy season) and OUT D (dry season).

since they had $80.9 \%$ of the data's total variability. High temperature, dissolved oxygen, water flow, $\mathrm{BOD}_{5}$, chlorophyll-a, TDS, nitrate, nitrite and Total $\mathrm{P}$ in axis $1(57.2 \%)$ were negatively related and characterized group I of Cluster Analysis. On the other hand, site IB was positively characterized to this axis by high $\mathrm{pH}$, conductivity, alkalinity, SRP and thermotolerant coliforms. Axis 2 with data variance of $23.7 \%$ positively correlated group
II with high TSS and low Total P and SRP loading rates (Figure 4).

The variables $\mathrm{pH}$ and conductivity showed a similar behavior with higher averages were only collected at sites during the dry season, especially in the IB. Alkalinity was also higher at this site and lowest at IR. However, dissolved oxygen had the highest concentration at the site IA D and the lowest at the site IB (Table 1). 
Table 1. Seasons means and standard deviation of abiotic variables of the sampling sites. IA: Inlet water from aquaculture farm; IR: inlet channel of rainwater runoff; IB: inlet from UASB wastewater; OUT: outlet wetland; Cond: Conductivity; DO: Dissolved Oxygen; Alk: Alkalinity.

\begin{tabular}{lccccccc}
\hline \multirow{2}{*}{ Variables } & \multicolumn{3}{c}{ Dry } & & \multicolumn{3}{c}{ Rain } \\
\cline { 2 - 4 } & IA & IB & OUT & & IA & IR & OUT \\
\hline $\mathrm{pH}$ & $8.3 \pm 0.1$ & $10.0 \pm 0.5$ & $8.4 \pm 0.2$ & & $7.9 \pm 0.3$ & $7.7 \pm 0.4$ & $7.9 \pm 0.2$ \\
Cond $\left(\mu \mathrm{S} . \mathrm{cm}^{-1}\right)$ & $108.3 \pm 6.6$ & $2328.6 \pm 1315.9$ & $110.0 \pm 6$ & & $84.7 \pm 33.7$ & $75.5 \pm 20.9$ & $89.7 \pm 16.8$ \\
DO $\left(\mathrm{mg} \cdot \mathrm{L}^{-1}\right)$ & $8.0 \pm 1.1$ & $2.6 \pm 2$ & $7.2 \pm 0.6$ & & $6.1 \pm 0.5$ & $5.7 \pm 1.2$ & $6.0 \pm 0.6$ \\
Alk $\left(\mathrm{mg} \cdot \mathrm{L}^{-1}\right)$ & $76.3 \pm 28$ & $889.2 \pm 1603.6$ & $74.5 \pm 30.3$ & & $91.4 \pm 9.4$ & $55.4 \pm 20.4$ & $72.2 \pm 11.5$ \\
Flow $\left(\mathrm{m}^{3} \cdot \mathrm{h}^{-1}\right)$ & $30.6 \pm 7.5$ & $1.4 \pm 0.1$ & $8.8 \pm 1.5$ & & $41.6 \pm 9.9$ & $10.4 \pm 5.1$ & $25.5 \pm 6.2$ \\
\hline
\end{tabular}

High means concentrations for nitrite, ammonia, SRP, Total P, TSS, TDS and TC were found at inlet IB. Nitrate had the highest concentrations during the dry season, principally at the inlet site IA $\mathrm{D}$, whereas $\mathrm{BOD}_{5}$ was highest during the rainy season, especially at IA R. Further, IA D and IA R were the sites with the highest concentrations of chlorophyll-a (Table 2).

Loading rate data for nitrate and TDS were higher for sampling sites IA D and IA R, whereas for ammonia, $\mathrm{BOD}_{5}$ and chlorophyll-a were highest only for IA R. Nitrite had higher loading rates not only at IA D and IA R but also at OUT R. IB was the main inlet of SRP loading rate whereas IA D and IB were the highest means for Total P. Sampling sites had higher rates for TSS during the rainy season than those collected during the dry one (Table 2).

Highest removal efficiencies rates from concentration and loading rate data occurred during the dry season with the exception of concentration data for $\mathrm{BOD}_{5}$ and chlorophyll-a, which were highest during the rainy season. When removal efficiencies rates between concentration and loading rate data during the dry season were compared, highest removal rates were found in the concentration of nitrite, ammonia, SRP, Total P, TSS and TDS; in the case of loading rate data the highest were for variables $\mathrm{BOD}_{5}$, nitrate and chlorophyll-a. Only nitrite, SRP, Total P and TSS had the highest removal efficiencies rates in concentration data during the rainy period. All the other variables had the highest removal rates for loading data in this season (Table 2).

\section{Discussion}

Hydraulic loading rate and water temperature characteristics followed the regional seasonal trends. According to Tanner (1996), the climate of the place where the assay was conducted is extremely important in the effluent treatment systems since it affects the biological processes that regulate nutrient removal in the wetlands. Precipitation affects detention time and, consequently, influences the nutrients and solids removal efficiencies in the wetlands (Kuschk et al., 2003), as current investigation shows.

Variation in water volume and flow are factor that may affect the amount of pollutants discharged into the treatment system and capacity to remove the compounds. Although UASB wastewater had higher concentrations of nitrogen, phosphorus and solids, the loading rate data, which were influenced by water volume, indicated that effluents with great flow, such as inlet water from aquaculture farm (dry and rainy season) can cause a faster degradation process of water quality in receiving water bodies.

The inlet water from aquaculture farm had high concentrations only for TSS and $\mathrm{BOD}_{5}$ in the rainy season due to allochthonous particles and sediment re-suspension caused by rain. In the case of other variables analyzed in this sampling site, rain was a dilution factor since concentrations were equal or less that those during the dry season.

Loading rate data, however, showed that inlet water from aquaculture farm for the two climatic periods and the outlet water wetland during the rainy season mainly caused the high loading rate of all forms of inorganic nitrogen, Total P, TDS, $\mathrm{BOD}_{5}$, chlorophyll-a and DO, mainly due to the high flow from the ponds of the water organisms production system. These sites, especially during the rainy season, had the worst water quality owing to the high discharge of large quantities of organic particles to the constructed wetland and to reduced retention time in the system which affected the removal efficiency. Filtration, sedimentation, adsorption, inactivation and microbial metabolism processes were the main mechanisms that decreased rates of the variables $\mathrm{BOD}_{5}$, chlorophyll-a, TSS, TDS, Total P, nitrogen and TC (Boutilier et al., 2009). Akratos et al. (2008) and Sindilariu et al. (2009) reported that greater detention time water in constructed wetlands was the most important positive factor in pollutants removal efficiency. 


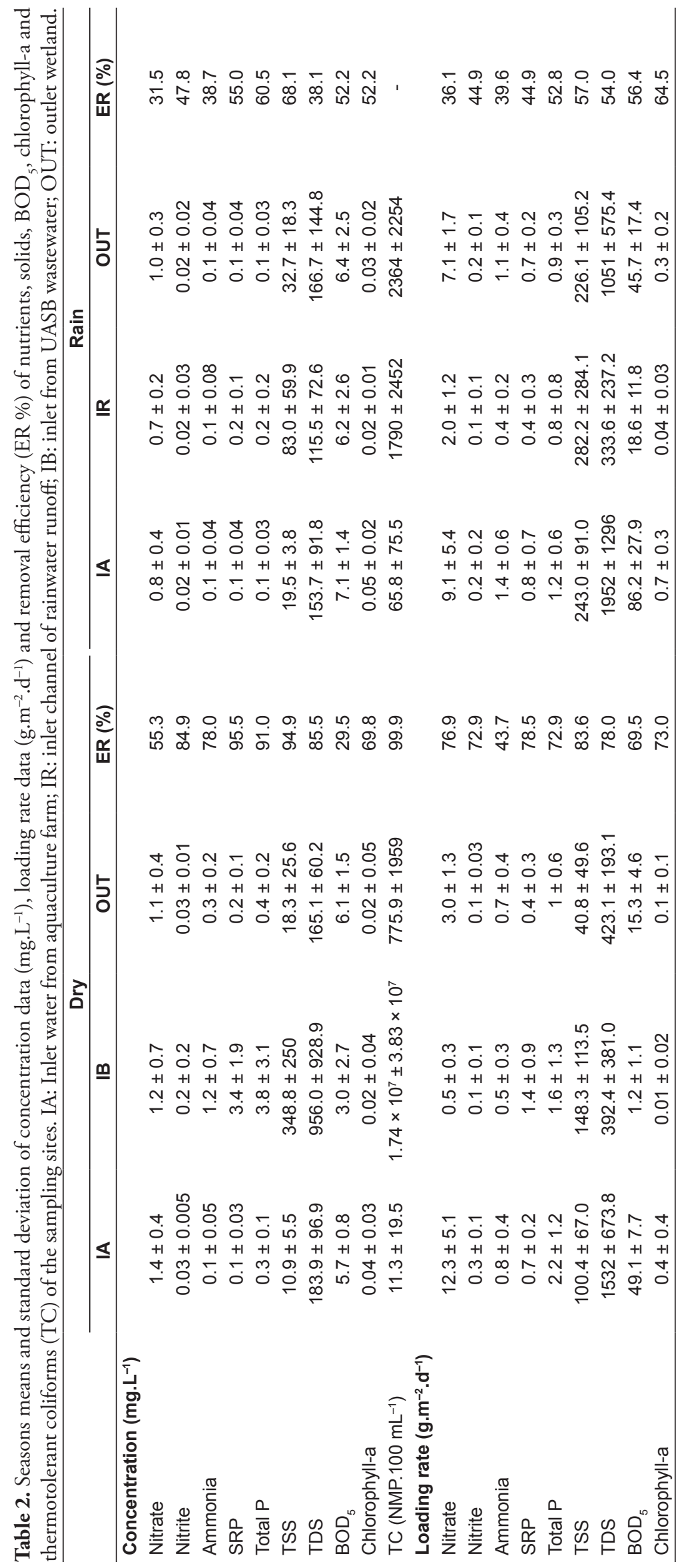


Current study showed that high water inflow in the system due to the rainy season made difficult the filtration and sedimentation of particles and the metabolism of the microbial community. This fact caused less efficiency in the rate decrease of loading rate variables when compared to the dry season.

During the rainy season the sampling site IR was the inflow with the highest concentrations in ammonia, SRP, Total P, TSS and TC, with an increase of concentrations in the water of the constructed wetland. Undoubtedly this fact made the treatment by the system more difficult during the rainy season. Inlet channel of rainwater runoff also contributed towards TSS high loading rate which might have affected the low performance of treatment during the period. In fact, organic and suspended solids loading rates were the main parameters that influenced the treatment's obstruction process (Dahab and Surampalli, 2001). As a consequence, TC increased at the outlet wetland during the rainy season. This was probably due to a higher concentration of nutrients and solids with the same pattern. In fact, nutrients provided resources for the metabolism of microorganisms and rates of suspended solids increased the survival of bacteria (Boutilier et al., 2009).

The UASB wastewater had the highest concentration of nutrients and organic matter. Despite anaerobic biodigestion is an alternative method for the treatment of animal wastes, it has been reported that effluents from UASB contain organic and inorganic compounds and pathogenic microorganisms at concentrations which are higher than standards recommended for the elimination in water sources (Kaseva, 2004), as occurred in this study. Further treatments are required before wastes reached the wetland under analysis so that the water outflow of the treatment might be reused.

Thermotolerant coliforms had a higher rate only at IB, since biodigesters used cattle, pig and fowl feces rich in TC as reaction materials. Cattle feces have been identified as the main reservoir of Escherichia coli, a highly potent transmission vector to the environment, animals and food (Wang et al., 1996). Amaral et al. (2004) verified that biodigesters significantly decrease total and thermotolerant coliforms in the anaerobic biodigestion process in reactors in India and China, even though they still exhibited high rates of TC in the effluent.

The removal of TC by constructed wetland system occurs by the presence of macrophytes, which reduce the number of pathogenic bacteria due to the excretion of inhibiting metabolites and the stimulation of preying microorganisms in the rhizosphere (Kouki et al., 2009). In this study, the high removal rate of TC observed during the dry season may be attributed to presence of macrophytes and dilution by wetland water, which better performance due to hydraulic characteristics of the period.

Owing to the biodigestion process of animaloriginated organic material, IB caused high $\mathrm{pH}$, conductivity and alkalinity, coupled to low rates in $\mathrm{DO}$ and $\mathrm{BOD}_{5}$ in the concentration and loading rate analysis. Low rates were the consequence of anaerobic treatment in the biodigesters in which DO concentrations were reduced with the subsequent aerobic decomposition of organic material.

The $\mathrm{pH}$ was alkaline with higher rates during the dry season, mainly at the inlet from UASB wastewater. According to Maine et al. (2007), water with high $\mathrm{pH}$ might limit the growth of $E$. crassipes. In this study the water alkaline might have impaired the E. crassipes performance in the treatment. Aquatic macrophytes in water wetlands with high $\mathrm{pH}$ mainly provided a substratum so that the decomposing microorganisms raised free carbon dioxide rate in the column water (Mayes et al., 2009). The $\mathrm{CO}_{2}$ from the respiration of microorganisms in the constructed wetland might have helped in the decrease of $\mathrm{pH}$ at the outlet.

Low water volume in the constructed wetland during the dry season increased conductivity of the entire system. This fact was due to high $\mathrm{pH}$ caused by high concentrations of hydroxyls in the environment, carbonates, bicarbonates, sulfates, ammonia and other ions from the biodigestion of organic matter, especially after the inlet from UASB wastewater. High alkaline water wetland may have been related to the high presence of calcium compounds, because according to Mayes et al. (2009) the hydrolysis of calcium compounds produces the hydroxyl ion, which elevates solution $\mathrm{pH}$ and releases $\mathrm{Ca}^{+}$ions in the wetland. A decrease in conductivity was reported during the dry season, probably due to the dilution of the compounds in the wetland water and to the assimilation and metabolism of calcium, magnesium, potassium, sodium and other ions by the microorganisms and plants in the wetland.

Removal of phosphorus compounds during the rainy season and mainly during the dry one was related to the alkalinity of water and to absorption by macrophytes. Due to DO concentration increase at the outlet wetland, a high potential redox might 
have occurred with the adsorption of phosphorus and iron hydroxides, and their fixture on the sediment. Maine et al. (2007) also reported this type of process.

Intensification of nitrification and denitrification occurred at the 6.5-8 $\mathrm{pH}$ range (Tao and Wang, 2009) and intensification of the volatilization of ammonia with pH over 8.5 (Vymazal, 2007). Current study evidenced nitrogen decrease during the dry season which occurred through the absorption by plants and microorganisms and by the loss of nitrogen in the atmosphere. DO highest concentrations at IA D and OUT D might be associated to a greater transparency of the water column which allowed greater light penetration and promoted the photosynthesis of algae, and thus affecting nitrification rates. High DO in wetlands causes the nitrification process through a decrease in ammonia levels and an increase of nitrates (Faulwetter et al., 2009). Whereas nitrifying bacteria also to use $\mathrm{CO}_{2}$ and bicarbonate for cell synthesis, they also employ ammonia and nitrite as energy sources, with the consequent reduction of these compounds in the water column (Spieles and Mitsch, 2000).

As a rule, in current study water treatment was positively affected by detention time. Best removal efficiency during the dry season was similar to that of other researchers conducted in tropical climates (Olguín and Sánchez-Galván, 2010), although hydraulic loading rate in the wetland under analysis was higher.

In summary, the results showed the relevance of concentration and loading rate data analysis. Although inlet from UASB wastewater had the greatest concentrations for most variables, the inlet water from aquaculture farm greatly contributed towards the degradation process of the source in the two climatic periods when flow was taken into account. Rain diluted the compounds from aquaculture farm, with the exception of organic matter and suspended solids. This was due to the resuspension of the sediment, whilst the inlet channel of rainwater runoff contributed towards large concentrations of allochthone material. Moreover, high quantity of solids carried to the system and the increase in hydraulic loading rate during the period impaired the removal process of effluent pollutants.

The constructed wetland was efficient in removing nutrients, solids, $\mathrm{BOD}_{5}$, chlorophyll-a and TC, mainly for the dry season, probably due to greater concentrations in treatment inflows and lower rates of hydraulic loading rate when compared to rates during the rainy season. Water from aquaculture farm might be treated by the constructed wetland system improving to increase the removal efficiency rates through an increase in detention time. The passage of UASB wastewater by a pre-treatment prior to discharge in the wetlands was indicated for greater removal efficiency.

\section{Acknowledgements}

This study was supported by Fundação de Amparo à Pesquisa do Estado de São Paulo (FAPESP) (processes no 2006/50315-4 and 2008/56621-5). We also acknowledge the working group of the Laboratory of Limnology and Plankton Production (UNESP-CAUNESP) for help in the laboratory and field analyses, and Valdecir Fernandes de Lima and Mauro Marcelino for their assistance in the experiment construction and maintenance.

\section{References}

AKRATOS, CS., PAPASPYROS, JNE and TSIHRINTZIS, VA. 2008. An artificial neural network model and design equations for BOD and COD removal prediction in horizontal subsurface flow constructed wetlands. Chemical Engineering, vol. 143, no. 1-3, p. 96-110. http://dx.doi. org/10.1016/j.cej.2007.12.029

AMARAL, CMC., AMARAL, LA., LUCAS JUNIOR, J., NASCIMENTO, AA., FERREIRA, DS. and MACHADO, MRF. 2004. Biodigestão anaeróbia de dejetos de bovinos leiteiros submetidos a diferentes tempos de retençáo hidráulica. Ciência Rural, vol. 34, no. 6, p. 1897-1902. http://dx.doi.org/10.1590/ S0103-84782004000600035

AN, Y., WU, B., WONG, FS. and YANG, F. 2010. Posttreatment of upflow anaerobic sludge blanket effluent by combining the membrane filtration process: fouling control by intermittent permeation and air sparging. Water and Environment Journal, vol. 24, no. 1 , p. 32-38. http://dx.doi.org/10.1111/j.17476593.2008.00152.x

BARROS, P., RUIZ, I. and SOTO, M. 2008. Performance of an anaerobic digester-constructed wetland system for a small community. Ecological Engineering, vol. 33, no. 2, p. 142-149. http://dx.doi.org/10.1016/j. ecoleng.2008.02.015

BOUTILIER, L., JAMIESON, R., GORDON, R., LAKE, C. and HART, W. 2009. Adsorption, sedimentation, and inactivation of $E$. coli within wastewater treatment wetlands. Water Research, vol. 43, no. 17 , p. 4370-4380. PMid:19595429. http://dx.doi.org/10.1016/j.watres.2009.06.039

BOYD, CE. and TUCKER, CS. 1992. Water quality and pond soil analyses for aquaculture. Alabama: Agricultural Experiment Station. 183 p. 
BRIX, H., KOOTTATEP, T. and LAUGESEN, CH. 2007. Wastewater treatment in tsunami affected areas of Thailand by constructed wetlands. Water Science Technology, vol. 56, no. 3, p. 6974. PMid:17802840. http://dx.doi.org/10.2166/ wst.2007.528

CRAB, R., AVNIMELECH, Y., DEFOIRDT, T., BOSSIER, P. and VERSTRAETE, W. 2007. Nitrogen removal techniques in aquaculture for a sustainable production. Aquaculture, vol. 270, no. 1-4, p. 1-14. http://dx.doi.org/10.1016/j. aquaculture.2007.05.006

DAHAB, MF. and SURAMPALLI, RY. 2001. Subsurfaceflow constructed wetlands treatment in the plains: five years of experience. Water Scientific and Technology, vol. 44, no. 11, p. 375-380. PMid:11804121.

EL-KHATEEB, MA., AL-HERRAWY, AZ., KAMEL, MM. and EL-GOHARY, FA. 2009. Use of wetlands as post-treatment of anaerobically treated effluent. Desalination, vol. 245, no. 1-3, p. 50-59. http:// dx.doi.org/10.1016/j.desal.2008.01.071

FAULWETTER, JL., GAGNON, V., SUNDBERG, C., CHAZARENC, F., BURR, MD., BRISSON, J., CAMPER, AK. and STEIN, OR. 2009. Microbial processes influencing performance of treatment wetlands: a review. Ecological Engineering, vol. 35, no. 6, p. 987-1004. http://dx.doi.org/10.1016/j. ecoleng.2008.12.030

GOLTERMAN, HL., CLYMO, RS. and OHNSTAD, MAM. 1978. Methods for physical and chemical analisys of freshwater. London: Blackwell Sci. Publ. 213 p.

GREENBERG, AE., CLESCERI, LS. and EATON, AD. 1992. Standart methods for examination of water and wastewater. Washington: American Public Health Association. 1100 p.

HENRY-SILVA, GG. and CAMARGO, AFM. 2008. Tratamento de efluentes de carcinicultura por macrófitas aquáticas flutuantes. Revista Brasileira de Zootecnia, vol. 37, no. 2, p.181-188. http://dx.doi. org/10.1590/S1516-35982008000200002

KAISER, HF. 1958. The varimax criterion for analytic rotation in factor analysis. Psychometrika, vol. 23, no. 3, p. 187-200. http://dx.doi.org/10.1007/ BF02289233

KASEVA, ME. 2004. Performance of a sub-surface flow constructed wetland in polishing pre-treated wastewater - a tropical case study. Water Research, vol. 38, no. 3, p. 681-687. PMid:14723937. http:// dx.doi.org/10.1016/j.watres.2003.10.041

KATSENOVICH, YP., HUMMEL-BATISTA, A., RAVINET, AJ. and MILLER, JF. 2009. Performance evaluation of constructed wetlands in a tropical region. Ecological Engineering, vol. 35, no. 10, p. 1529-1537. http://dx.doi.org/10.1016/j.ecoleng.2009.07.003
KINDT, R. and COE, R. 2005. Tree diversity analysis: A manual and software for common statistical methods for ecological and biodiversity studies. Nairobi: World Agroforestry Centre (ICRAF). 204 p.

KONNERUP, D., TRANG, NTD. and BRIX, H. 2011. Treatment of fishpond water by recirculating horizontal and vertical flow constructed wetlands in the tropics. Aquaculture, vol. 313, no. 1-4, p. 57-64. http://dx.doi.org/10.1016/j. aquaculture.2010.12.026

KOROLEFF, F. 1976. Determination of ammonia. In GRASSHOFF, K. and ALMGREEN, T., ed. Methods of seawater analysis. German: Verlag Chemie Wenhein. p. 126-133.

KOUKI, S., M'HIRI, F., SAIDI, N., BELAÏD, S. and HASSEN, A. 2009. Performances of a constructed wetland treating domestic wastewaters during a macrophytes life cycle. Desalination, vol. 246, no. 1-3, p. 452-467. http://dx.doi.org/10.1016/j. desal.2008.03.067

KUSCHK, P., WIEBNER, A., KAPPELMEYER, U., WEIBBRODT, E., KÄSTNER, M. and STOTTMEISTER, U. 2003. Annual cycle of nitrogen removal by a pilot-scale subsurface horizontal flow in a constructed wetland under moderate climate. Water Research, vol. 37, no. 17, p. 4236-4242. http://dx.doi.org/10.1016/S00431354(03)00163-5

MACKERETH, FJH., HERON, J. and TALLING, FJ. 1978. Water analyses: some revised methods for limnologists. Cumbria: Freshwater Publication Association Scientific Publication. 120 p.

MAINE, MA., SUÑE, N., HADAD, H., SÁNCHEZ, G. and BONETTO, C. 2007. Removal efficiency of a constructed wetland for wastewater treatment according to vegetation dominance. Chemosphere, vol. 68, no. 6, p. 1105-1113. PMid:17346771. http:// dx.doi.org/10.1016/j.chemosphere.2007.01.064

MAYES, WM., BATTY, LC., YOUNGER, PL., JARVIS, AP., KÓIV, M., VOHLA, C. and MANDER, U. 2009. Wetland treatment at extremes of $\mathrm{pH}$ : A review. Science of the total environment, vol. 407, no. 3, p. 944-957. PMid:18706678. http:// dx.doi.org/10.1016/j.scitotenv.2008.06.045

NUSCH, EA. 1980. Comparison of different method for cholophyll and pheopigments determination. Archiv für Hydrobiologie, vol. 14, p. 14-36.

OLGUÍN, EJ. and SÁNCHEZ-GÁLVAN, G. 2010. Aquatic phytoremediation: Novel insights in tropical and subtropical regions. Pure and Applied Chemistry, vol. 82 , no. 1, p. 27-38. http://dx.doi.org/10.1351/ PAC-CON-09-02-13

OLIVEIRA, RA. and SANTANA, AM. 2011. Swine wastewater treatment in upflow anaerobic sludge blanket reactor (UASB) in two-stages followed by 
sequencing batch reactor (SBR). Engenharia Agricola, vol. 31, no. 1, p. 178-192.

PISTORI, RET., HENRY-SILVA, GG., BIUDES, JFV. and CAMARGO, AFM. 2010. Influence of aquaculture effluents on the growth of Salvinia molesta. Acta Limnologica Brasiliencia, vol. 22, no. 2, p. 179-186.

SINDILARIU, PD., BRINKER, A. and REITER, R. 2009. Factors influencing the efficiency of constructed wetlands used for the treatment of intensive trout farm effluent. Ecological Engineering, vol. 35, no. 5, p. 711-722. http://dx.doi. org/10.1016/j.ecoleng.2008.11.007

SIPAÚBA-TAVARES, LH. and BRAGA, FMS. 2008. Constructed wetland in wastewater treatment. Acta Scientiarum - Biological Sciences, vol. 30, no. 3, p. 261-265.

SIPAÚBA-TAVARES, LH., LOURENÇO, EM. and BRAGA, FMS. 2010. Water quality in six sequentially disposed fishponds with continuous water flow. Acta Scientiarum, vol. 32, no. 1, p. 9-15.

SPIELES, DJ. and MITSCH, WJ. 2000. The effects of season and hydrologic and chemical loading on nitrate retention in constructed wetlands: a comparison of low and high nutrient riverine systemsit. Ecological Engineering, vol. 14, no. 1-2, p. 77-91. http://dx.doi. org/10.1016/S0925-8574(99)00021-X

Statsoft, Inc. Statistica. 2007. Data analysis software system. version 8.0. Available from: <www.statsoft. com>.

STONE, KC., POACH, ME., HUNT, PG. and REDDY, GB. 2004. Marsh-pond-marsh constructed wetland design analysis for swine lagoon wastewater treatment. Ecological Engineering, vol. 23, no. 2, p. 127-133. http://dx.doi.org/10.1016/j.ecoleng.2004.07.008
TANNER, CC. 1996. Plants for constructed wetland treatment systems - A comparison of the growth and nutrient uptake of eight emergent species. Ecological Engineering, vol. 7, no. 1, p. 59-83. http://dx.doi. org/10.1016/0925-8574(95)00066-6

TAO, W. and WANG, J. 2009. Effects of vegetation, limestone and aeration on nitritation, anammox and denitrification in wetland treatment systems. Ecological Engineering, vol. 35, no. 5, p. 836-842. http://dx.doi.org/10.1016/j.ecoleng.2008.12.003

TOLEDO, JJ. and PENHA, J. 2011. Performance of Azolla caroliniana Willd. and Salvinia auriculata Aubl. on fish farming effluent. Brazilian Journal of Biology, vol. 71, no. 1, p. 37-45. PMid:21437397. http:// dx.doi.org/10.1590/S1519-69842011000100007

VON SPERLING, M. and OLIVEIRA, SC. 2009. Comparative performance evaluation of full-scale anaerobic and aerobic wastewater treatment processes in Brazil. Water Science \& Technology, vol. 59, no. 1, p. 15-22. PMid:19151481. http://dx.doi. org/10.2166/wst.2009.841

VYMAZAL, J. 2007. Removal of nutrients in various types of constructed wetlands. Science of the Total Environment, vol. 380, no. 1-3, p. 48-65. PMid:17078997. http://dx.doi.org/10.1016/j. scitotenv.2006.09.014

WANG, G., ZHAO, T. and DOYLE, MP. 1996. Fate of enterohemorrhagic Escherichia coli 0157:H7 in bovine feces. Applied Environmental Microbiology, vol. 62, no. 7, p. 2567-2570. PMid:8779595 PMCid:168038.

ZURITA, F., DE ANDA, J. and BELMONT, MA. 2009. Treatment of domestic wastewater and production of commercial flowers in vertical and horizontal subsurface-flow constructed wetlands. Ecological Engineering, vol. 35, no. 5, p. 861-869. http://dx.doi. org/10.1016/j.ecoleng.2008.12.026

Received: 28 November 2011 Accepted: 01 November 2012 